\title{
Not Just the Luck of the Draw? Exploring Competency of Counsel and Other Qualitative Factors in Federal Court Refugee Leave Determinations (2005-2010)
}

JAMIE LIEW, PIA ZAMBELLI, PIERRE-ANDRÉ THÉRIAULT, AND MAUREEN SILCOFF ${ }^{1}$

\section{Abstract}

Refugee claimants who have received a negative decision from the Immigration and Refugee Board sometimes seek judicial treview at the Federal Court in Canada. Previous statistical studies, in particular Sean Rehaag's (2012) study, "The Luck of the Draw," have reported that rejected refugee claimants seeking judicial review face low and inconsistent leave grant rates, with chances of success largely dependent on judge assignment. The present research looks beyond these quantitative findings to identify additional factors that may explain the troubling statistics. To this end, four researchers manually reviewed 50 leave applications submitted between 2005 and 2010 and included in Rehaag's (2012) data set. The results of this qualitative analysis are

1. Thanks are due to the editors and peer reviewers for their invaluable suggestions, as well as to the Registry of the Federal Court. Thank you to Angus Grant, Diane Nancy Doray, Cristina Rogov, and Adam Sandinsky for their assistance. We would also like to thank students at the University of Ottawa, Faculty of Law (Aditya Rao, Caroline Nguyen, Danny Yeo, Sarah Dodsworth, Salman Rana, Mariam Gagi, Janssen Dangzalan, Ursula Salas, and Gurpriya Kaberwal) for their research assistance in obtaining copies of full case files at the Federal Court. The authors have much gratitude for the helpful comments given by Hilary Evans Cameron and the commenters and organizers at both the 2018 Canadian Immigration Law Scholars Conference and the 2018 Ottawa Immigration Law Conference. Any opinions expressed in this article are those of the authors and should not be attributed to any organization of which they are or may have been a member.

\footnotetext{
(C) Jamie Liew et al., 2021. This open-access work is licensed under a Creative Commons Attribution-NonCommercial 4.o International Licence, which permits use, reproduction, and distribution in any medium for non-commercial purposes, provided the original authorship is credited and the original publication in Refuge: Canada's Journal on Refugees is cited.
}

Cette œuvre en libre accès fait l'objet d'une licence Creative Commons Attribution-NonCommercial 4.o International License, laquelle autorise l'utilisation, la reproduction et la distribution de l'œuvre sur tout support à des fins non commerciales, pourvu que l'auteur ou les auteurs originaux soient mentionnés et que la publication originale dans Refuge: revue canadienne sur les réfugiés soit citée. 
disturbing: a significant number of rejected leave applications had been poorly prepared, and a number of facially strong cases were denied leave. These results suggest that leave grant rates could rise if the quality of legal representation were enhanced. They also indicate that rejected refugee claimants would benefit from clear and uniformly applied criteria for granting leave.

\section{Résumé}

Les demandeurs d'asile ayant reçu une décision négative de la Commission de l'immigration et du statut de réfugié font parfois une demande en révision judiciaire à la Cour fédérale du Canada. Des études statistiques antérieures, et particulièrement l'étude de Sean Rehaag (2012) «The Luck of the Draw", ont signale que les demandeurs d'asile déboutés demandant une révision judiciaire font face à des taux d'acceptation des demandes d'autorisation bas et inconstants, les chances de succès dépendant largement du juge désigné. La présente recherche cherche à aller au-delà de ces résultats quantitatifs afin d'identifier des facteurs additionnels pouvant expliquer ces statistiques troublantes. À cette fin, quatre chercheurs ont révisé manuellement 50 demandes d'autorisation soumises entre 2005 et 2010, un échantillon des dossiers examinés par Rehaag (2012). Les résultats de cette analyse qualitative sont inquiétants. Un nombre significatif de demandes d'autorisation rejetées ont été mal préparées et un nombre de cas de prime abord solides se sont vus refuser l'autorisation. Ces résultats suggèrent que les taux d'autorisations accordées pourraient augmenter si la qualité de la représentation légale était améliorée. Ils indiquent également que les demandeurs d'asile déboutés bénéficieraient de la mise en place de critères clairs et uniformément appliqués en ce qui concerne l'acceptation des demandes d'autorisation.

\section{Introduction and Overview: The Need to Go Beyond Numbers}

Canada is touted internationally as having a refugee determination system designed to respect the principles of natural justice and fairness (Barutciski, 2012, p. 5). Refugee claimants within Canada have a right to an oral hearing at the Refugee
Protection Division (RPD) of the Immigration and Refugee Board (IRB) (Singh $v$ Canada, 1985). Negative RPD decisions can be appealed to the Refugee Appeal Division (RAD) of the IRB and/or judicially reviewed at the Federal Court of Cana$\mathrm{da}$ (Immigration and Refugee Protection Act, 2001). ${ }^{2}$ In order to have a decision judicially reviewed, however, leave must first be granted (Immigration and Refugee Protection Act, 2001, s 72(1)).

Previous statistical studies have reported that rejected refugee claimants seeking judicial review before the Federal Court face low and inconsistent leave grant rates (Rehaag, 2012). This preliminary research attempts to look beyond the quantitative findings in Sean Rehaag's 2012 study that concluded that judge selection plays the dominant role in leave grant rates. To this end, we undertook a manual review of 50 leave files included in Rehaag's 2012 data set, in order to examine the nature and quality of the materials filed and better understand what qualitative factors affect the decision-making process.

The original intent of the present study was to expand on existing quantitative studies of the leave requirement. This study, to our knowledge, is the first qualitative review undertaken. As it turned out (and quite unexpectedly), our findings potentially have implications for other areas of scholarship as well-specifically, the study of the role of counsel in legal proceedings generally. In addition to serious issues in the legal soundness of the leave determinations themselves, we found a pattern of substandard representation by counsel throughout the case files, which correlated with below-average leave outcomes. This raises the question of whether the poor leave outcomes highlighted by Rehaag and others might hinge on multiple factors beyond judge assignment-factors that include quality of representation. As lawyers, the possibility of a counterpoint to the "luck of the draw" narrative prompts us to wonder whether (to quote Cassius, in Julius Caesar), "The fault, dear Brutus, is not in our stars, / But in ourselves, that we are underlings" (Shakespeare, 1984, 1.2.140-141).

\section{Why Are Leave Determinations Important?}

In Canada, rejected refugee claimants do not enjoy unfettered access to judicial review of the decision denying them asylum; it has long been the case that they (and all immigrants, for that matter) must first seek "leave" of the Feder-

2. Some refugee claimants do not have access to the RAD: those whose claim was referred as an exception to the Safe Third Country Agreement, Designated Foreign Nationals (mass land or sea arrivals), those whose claim was found to be manifestly unfounded and/or to have no credible basis, those whose claim was abandoned or withdrawn, and those whose claim was referred to the Immigration and Refugee Board before the RAD was implemented in December 2012 ("legacy claims"). All claimants, including those who do not have access to the RAD, can apply for leave for judicial review at the Federal Court. 
al Court. ${ }^{3}$ This arrangement was referred to by the court in Arulampalan (1989) as a "right" to judicial review "subject to prior approval." Legal scholars have noted, however, that the leave requirement, particularly in the refugee context, "directly and incontrovertibly breaches" the "guarantee of access to an independent and impartial court," which is "one of the foundational tenets of the rule of law" (Macklin, 2009, pp. 105-105). Leave determinations are high stakes affairs: if a negative determination of refugee status is made, the individual in question becomes subject to removal to the country he or she fled. If the initial determination was wrong or unfairly reached and the decision is not scrutinized by a judge, then removal could mean persecution or even death.

In theory, the leave requirement should not pose a threat to refugees, because the test for leave is quite low. The Federal Court of Appeal noted in Bains v Canada (1990),

The only question to be considered in disposing of an application for leave under those provisions is whether or not a fairly arguable case is disclosed for the relief proposed to be sought if leave were to be granted.

Shortly thereafter, in Virk $v$ Canada (1991) the Federal Court explained the test for leave as follows:

\begin{abstract}
The purpose of the amendment to the Act in s. 82.1, requiring leave to file a s. 18 application, is to prevent the Court being flooded with s. 18 applications, made in many cases without any merit, merely to secure further delays so the applications for leave should not be lightly granted. On the other hand, if there appears to be any possibility of applicant succeeding at the hearing of the s. 18 application, applicant should be given the benefit of the doubt and given leave. Granting of leave does no more than give the applicant an opportunity for a full hearing on a s. 18 application and, therefore, should not consider in depth the merits of the proposed s. 18 application.
\end{abstract}

Nonetheless, in practice, the leave grant rate has historically been much lower than the test itself would suggest it should be: only $16 \%$ in refugee cases in 2005-2010 (Rehaag, 2012, Table 7) ${ }^{4}$ and $22.2 \%$ currently (Rehaag, 2019, Table 3).5 There have also been wide disparities in grant rates amongst judges, ranging from $77.97 \%$ to $1.36 \%$ in $2005-2010$ (Rehaag, 2012, Table 2), and ranging from $49.2 \%$ to $5.3 \%$ currently (Rehaag, 2019, Table 2).

With attempts to challenge its constitutionality perfunctorily dismissed (Arulampalam, 1989; Bains, 1990; Krishnapillai v Canada, 2001; Rehaag, 2019, pp. 37-38), the leave requirement remains an obstacle to fair and accurate refugee status determination in Canada. Even though most claimants now enjoy a right to a fact-based administrative appeal of negative decisions before the RAD, the RAD itself is not fool-proof and requires judicial scrutiny. A quantitative study of outcomes at the RAD conducted by Rehaag and Grant (2016) revealed inconsistent grant rates between RAD members and widely diverging views on the level of deference owed to RPD decisions. Accordingly, more resources, research, and attention must be devoted to the nature of the leave function in judicial review of refugee determinations, and the present qualitative study seeks to increase understanding and awareness in this regard. This is especially important given that, for the many refugee claimants who are barred from accessing the RAD appeal, ${ }^{6}$ the only recourse they may have is judicial review.

\section{Previous Studies of the Federal Court Leave Requirement}

The low and inconsistent grant rates have prompted researchers to hypothesize that the problem lies with the predisposition of individual judges. Several studies of the Federal Court leave requirement undertaken by legal scholars essentially support that hypothesis. All have been largely quantitative and have relied on varying data sets, making it somewhat difficult to generalize about the findings and to definitively determine to what extent such a hypothesis is correct. Since the initial goal of the present study was to add to and situate itself within this literature, ${ }^{7}$ it is important to review it briefly.

An initial study by Greene and Shaffer (1992) was based on a sample of 611 out of some 2,00o refugee and non-refugee leave applications filed in 1990. ${ }^{8}$ They found an unusual and pronounced degree of difference in leave grant rates amongst judges (p. 82) and concluded that "an association exists between individual judges on the Federal Court of Appeal and the rate of success of applicants for leave to appeal" (p. 81).

3. The leave requirement was introduced in the 1989 amendments to the Immigration Act, 1976, sC 1976-77, c 52, s 82.1h.

4. This figure excludes cases where the minister was the applicant and cases that were not opposed, discontinued, or not perfected.

5. Again, excluding the same types of cases as above.

6. See note 1.

7. Our ultimate findings relative to the impact of counsel in leave applications could also situate the present study within a broader range of literature on the effectiveness of counsel in the overall refugee context and beyond. This literature will be referred to in the "Implications" section.

8. At the time of the Green and Shaffer study, leave applications were decided by the Federal Court of Appeal. 
This association remained strong, even when factoring in the possible effect of the human rights record of the claimant's country of origin (p. 80). These results were confirmed in a subsequent study conducted by Greene et al. (1998), which looked at all 2,081 applications filed in 1990.

A study by Gould et al. (2010) found that a number of factors were correlated to leave outcomes to a statistically significant level, including the existence and experience of counsel ("legal resource" factors), the region of filing, the gender, age, and nationality of the applicant ("structural" factors), and the gender of the judge and the judge's ideology ("judicial influence" factors) (p. 472). Interestingly for the purposes of the present study, Gould et al. found that representation by experienced legal counsel "strongly overshadowed the other explanations for the court's leave decisions" (p. 475). Ultimately, the authors acknowledged that their study did not "include a measure for legal legitimacy of the court's decisions" but still felt confident that the disparities they revealed strongly suggested that the Federal Court's immigration decisions "are heavily influenced by extralegal criteria" (p. 480).

Further research was conducted by Rehaag (2012), and this study is the work upon which the present study seeks to expand. In contrast to the previous studies, Rehaag's (2012) study was not based on a sample of leave decisions, but rather analyzed the entire body of leave applications filed during a given period (in total 23,000 leave applications filed between 2005 and 2010), and the study's data are disaggregated between applications filed by failed refugee claimants and those filed by the government. The stated goal of Rehaag's research was to examine "whether outcomes in these high-stakes applications turn on their merits or on which judge is assigned to decide the application" (Rehaag, 2012, p. 2). Like Greene and Shaffer (1992), Rehaag found massive variability in leave grant rates from judge to judge. As well, Rehaag noted that, despite a low leave grant rate in refugee cases, the overall grant rate on judicial review was relatively high-two to three times higher than the leave grant rate (Rehaag, 2012, p. 51). ${ }^{9}$ His inference on this score was that "some applications that could well succeed before most JR judges are prevented from reaching the merits stage by the fact that some leave judges are predisposed to deny leave" (p. 30). The overall conclusion of the Rehaag (2012) study was that outcomes in leave applications hinge partly on judge assignment-i.e., the "luck of the draw" (p. 30).
After the present research was completed (but prior to publication), Rehaag followed up with an updated quantitative study focusing on 33,000 leave applications filed between 2008 and 2016 (Rehaag, 2019). Rehaag's updated study found that while leave rates and ultimate judicial review outcomes for rejected refugee claimants had increased after 2012, there remained large variation between judges (p. 12, Table 3 ) and therefore outsized influence of the "luck of the draw" (p. 17).

The quantitative studies have been disseminated to the refugee bar, Federal Court judges, and the media. There is anecdotal evidence that this research, particularly Rehaag's (2012) study, has influenced how refugee lawyers currently view the fairness of the leave process (Rehaag, 2019, pp. 2-3; Butler, 2011). Yet, because the research takes a largely individualist judge-based approach to disparities in the leave granting process, it could be argued that lawyers (and the legal profession generally) may be tempted to off-load responsibility for outcomes. A perceived inability to affect outcomes might disincentivize diligent representation. These considerations undergird the need for a qualitative examination of leave decision-making as a complement to the previous quantitative research.

\section{A Preliminary Qualitative Study of Leave Determinations}

The variation in leave grant rates among judges is far outside the norm, and leave grant rates remain low, depriving thousands of refugee claimants the opportunity to have a judge review their denials of asylum. But can we trust numbers to provide the whole picture? The Federal Court has been very concerned about the implications of the statistical findings. One judge stated, "The numbers will never get at whether there was a high degree of merit to the application or not" (Butler, 2011). ${ }^{10}$ In the same vein, the former chief justice noted, "My colleagues and I are aware of too many variables that can skew what the numbers purport to say" (Butler, 2011).

In fact, many factors can affect a judge's assessment of a case, and this may be why, as noted earlier, Gould et al. (2010) highlighted an unfulfilled need for an assessment of the legal legitimacy of leave decision-making. Accordingly, the present research attempts to go beyond numbers and examine, qualitatively, the merits of a number of leave decisions within the group of cases initially studied by Rehaag (2012). Our purpose is to explore in a preliminary way not only how the leave test has been applied in practice, but also whether "variables" such as the strength or weakness of the

9. For all applications filed by failed claimants, including applications that were not opposed, not perfected, or discontinued, the leave grant rate was $14.18 \%$, whereas the judicial review grant rate was $43.53 \%$. If only perfected, opposed applications are considered, the leave grant rate was $16.38 \%$ and the judicial review grant rate was $39.54 \%$.

10. The judge in question was reacting to Rehaag's 2012 research. 
underlying refugee claim and/or the quality of the claimant's legal representation play a role in low grant rates. Our study hopes to ignite discussion for the purpose of not only more research, but more reflection by the legal community on the factors that lead to a successful leave application. We do not wish to minimize the reported issues in adjudication, but simply to explore whether other factors could be brought into the equation.

\section{Methodology: Qualitative Review of 50 Leave Cases Overall Study Design and Case Selection}

We conducted an in-depth exploratory analysis of 50 Federal Court files submitted between 2005 and 2010. The file period examined mirrored that of the Rehaag (2012) study. The files chosen also reflected the same parameters used by Rehaag: we selected only leave applications filed by refugee claimants who received a negative determination of their claim by the IRB, and only leave applications that were determined on the merits (i.e., not ones that were determined on consent or ones that were dismissed because they had not been perfected). A set of 50 cases seemed consistent with the number of cases examined in other qualitative studies in the refugee field (Rousseau et al., 2002; Canadian Council for Refugees, 2012, 2014). ${ }^{11}$

The files were selected by generating a random integer that was then associated with a Federal Court docket number. We reviewed the recorded entries on each file (available on the Federal Court's website) to ensure that each file corresponded to our research criteria. Our method generated well over 50 files that met the criteria. We then adjusted the collection of files so as to align with Rehaag's (2012) overall findings on outcome ( $16 \%$ of refugee leave applications decided on the merits were allowed) and city of filing (37\% in Montreal, $56 \%$ in Toronto, and $7 \%$ in Vancouver or other cities). This was done in order to avoid over-sampling files with any particular attributes. Thus, our set of 50 case files comprised 8 files where leave was granted, 42 where leave was refused, 28 that were filed in Toronto, 18 that were filed in Montreal, and 4 that were filed in other cities ( 2 in Vancouver, 1 in Edmonton, and 1 in Calgary). Our aim was not to conduct statistical analysis via a random sample, but simply to get a snapshot of the types of leave applications filed, in the hopes of learning more about the leave application decision-making process than had been revealed in the quantitative studies. We acknowledge the significant limitations inherent in our sampling method from a statistical perspective, but our choice made the most sense to us as legal practitioners.

\section{Assembling a Research Group with Refugee and Federal Court Experience}

The study of the 50 files was conducted by the authors, with the help of an additional researcher. Our team is well versed in both refugee law and Federal Court practice and could objectively examine cases based on their experience across a range of roles within the refugee determination process. ${ }^{12}$ The groups included a law professor who also practises refugee law, a $\mathrm{PhD}$ candidate researching Federal Court cases in the refugee context, two lawyers who were formerly IRB members for five and seven years respectively, and one lawyer who, at the time, had extensive experience practising refugee law.

\section{Identification of Variables}

Although the research group was largely agnostic about what manual review of the leave files would reveal, we did have some ideas about things to look out for. We felt that there were two variables that, in the words of the former chief justice, "can skew what the numbers purport to say": (1) effectiveness of legal representation, and (2) the strength or weakness of the underlying refugee claims. In the first variable, since a leave application is a legal proceeding, it seemed uncontroversial that the existence and quality of counsel could play a role in outcomes. In the second variable, we hypothesized that, despite the existence of errors of law in the negative decision, judges may deny leave where the underlying claim is perceived as weak in order to conserve judicial resources. There would be little point in returning a case for redetermination only to have it denied again or potentially take resources away from meritorious claims. We also postulated the converse case where judges might grant leave in cases where the underlying claim was strong, even in the face of negative factors such as a facially reasonable decision or a poorly prepared leave application. Accordingly, data were collected on both variables.

\section{Data Collected}

On the basis of the documents contained in a typical leave application, ${ }^{13}$ and with our two variables in mind, we estab-

11. Rousseau et al. reviewed 40 hearings; the Canadian Council for Refugees reviewed 70 cases.

12. These varying roles could be described as "practitioner," “decision-maker," and "observer" (academic).

13. As prescribed by the Immigration Rules, leave applications filed by refugee claimants against negative refugee status determinations are decided on the basis of an Applicant's Record (sometimes referred to as an "Application Record") filed by the refused claimant, a Respondent's Record filed by the relevant government minister, and, in some cases, a reply memorandum, filed by 
lished a list of data to be collected. For each file we recorded the following: (1) the style of cause; (2) the date of filing; (3) the city of filing; (4) counsel's name; (5) the leave disposition; (6) the leave judge's name; (7) the judicial review disposition if leave was granted; (8) the applicant/claimant's country of origin; (9) his or her gender; (10) whether the case involved a family or a minor; (11) the ground(s) for the refugee claim; (12) the tribunal's reasons for refusing the claim; (13) the quality of the leave application itself; and (14) the researcher's overall impression of why leave had been granted or denied. Some of these data were for general identification and classification, some related to the variable of the strength or weakness of the underlying refugee claim, ${ }^{14}$ and some related to the variable of the quality of legal representation.

In regard to the latter variable, we established additional assessment criteria on the adequacy and effectiveness of the affidavit material and memoranda filed on behalf of the refugee claimant. Factors related to the affidavit material included: (1) compliance with the Rules; (2) format; (3) whether interpretation services were used; (4) whether the deponent was the applicant; (5) readability; and (6) whether the text and exhibits adequately recreated the record of the proceedings below. Factors related to the memoranda of argument included: (1) compliance with the Rules; (2) format; (3) inclusion of an overview, listing of issues, proper headings, proper citations; (4) readability; (5) summarization of facts; (6) issue identification; (7) quality of research and legal argument; (8) articulation of the test for leave; and (9) the filing of a reply memorandum. A pass or fail score was assigned to both form and substance of pleadings in accordance with the criteria outlined above. Failing scores in any area were highlighted. The goal was to reveal instances where a poorly prepared leave application could have led to information gaps in the mind of the judge, potentially leading to a negative outcome on the basis that the case for leave for judicial review had not been adequately proven.

Beyond just collecting data relevant to the two variables, the researchers also evaluated the soundness of the leave determinations by providing a general assessment of whether they believed that leave should have been granted, taking into consideration the leave criteria and the content of the leave application. We recognize that the researchers' assessment of whether leave should have been granted will always be an essentially subjective exercise. Nonetheless, we attempted to assemble a group of refugee law experts who could operate as objectively as possible. On the basis of their knowledge of refugees, refugee law, and the thousands of judicial review decisions that have been issued over the past decade(s), they evaluated the material in the case files against the established legal test for the granting of leave. Again, the goal was simply to look at the materials filed and record impressions.

The 50 files were divided amongst the researchers, and each was asked to fill in an Excel worksheet containing the assessment criteria for each file. The researchers operated independently and not by consensus. ${ }^{15}$ One test case had been assigned and reviewed by all the researchers to establish consistency in evaluating the criteria. Once review was complete, the data received from each researcher were compiled into a master document for analysis.

\section{Findings: Factors Beyond Judge Assignment Demographics of the 50 Cases}

Despite the fact that our set of files was not selected in strict accordance with the principles of random sampling, as it turned out, our case files were not skewed heavily in any one direction. There were a wide range of countries of origin represented (nine claimants from Mexico, four each from India and Colombia, three each from Israel, Haiti, China, and Russia, and one each from Uruguay, St. Vincent, Sri Lanka, Peru, Brazil, Pakistan, Guyana, Ghana, El Salvador, Paraguay, Ukraine, Kosovo, Nigeria, Tunisia, Dominican Republic, Angola, Bangladesh, Mauritania, Romania, Zimbabwe, and Kenya), and a fairly wide range of judges ( 24 of the 47 judges studied by Rehaag [2012] were represented in our case files). Furthermore, the aggregate average leave grant rate of our 24 judges was $17.8 \%$, close to the overall $16 \%$ leave grant rate reported in Rehaag (2012). Thirteen applications were filed by single female claimants, 27 by single males, and 10 by couples

the refugee claimant. The Applicant's Record must include one or more affidavits and a Memorandum of Argument. Since the judge does not at the leave stage have a copy of tribunal's record, it is up to the applicant/claimant to recreate that record for the judge by way of material filed in an affidavit. The Respondent's Record contains generally the same items (affidavit material where appropriate and a Memorandum of Argument).

14. Data relating to this variable were country of origin, basis of claim, family composition, gender, and reasons for refusal. Some countries have poor human rights records and some do not. Some attributes or fact situations can ground a protection claim and some cannot. Likewise, refusals based on the claimant's lack of personal credibility as a witness might make a judge disposed to view the claim as fraudulent or to take a more deferential stance towards the Board's decision.

15. This approach proved unproblematic: each researcher's findings exhibited a similar pattern to the findings of the other researchers in terms of assessment of variables and overall legal soundness. 
or families. ${ }^{16} \mathrm{~A}$ wide range of counsel was also represented in the case files.

\section{Findings on the Legal Soundness of the Leave Determinations}

The researchers' assessment of the overall legal soundness of the leave determinations (i.e., whether the test for leave was met) fell into three categories.

\section{Leave Determination Justified}

The first category comprised cases where the researchers felt that the leave determination (either positive or negative) was justified. Fifteen of the 50 files $(30 \%)$ fell into this category, including all 8 where leave was granted and 7 where leave was denied. Generally, these were cases where the IRB's decision was solid or the underlying refugee claim was weak. For example, in one file, the researcher concluded that the denial of leave was justifiable because at the IRB "key documents were sent for verification and came back fraudulent-this led to reasonable credibility concerns." In another, the researcher's comments were that "denial of leave was understandable. It was a justifiable credibility decision."

\section{Leave Determination Not Justified}

The second category comprised cases where the researchers felt that the leave determination was legally wrong. Thirteen of the 50 files $(26 \%)$ fell into this category. All of them were denied leave. These were cases where there were errors of law apparent on the face of the reasons or established by the materials filed. For example, in one such file, the researcher noted, "I believe leave should have been granted: the RPD panel ignored important evidence, including a corroborative letter and the fact that the applicant's father was granted refugee status on similar facts. These arguments were put to the court." In another, the researcher stated, "There was more than enough presented to have justified granting leave. The claim was strong, he complained $3 \mathrm{x}$ to the police. Serious allegation of rape in police custody."

\section{Leave Determination Potentially Affected by Poor Legal Representation}

There was a third category of cases that falls somewhere between the first two. This category comprised cases where the researchers could not assess the legal soundness of the leave determination because they felt that poor legal representation would have made it difficult, if not impossible, for the judge to have granted leave, despite indications that the tribunal's decision was otherwise erroneous. Twenty-two of the 50 files (44\%) reviewed fell into this category. In some instances, an error was apparent on the face of the reasons, but counsel had not adequately identified, addressed, or expounded on it in the application record. In other instances, counsel had failed to adequately recreate the record before the tribunal: this left the judge with little or no information to counter what was set forth in the reasons, rendering a denial of leave virtually inevitable. For example, in one file, the researcher found that the memorandum (factum) filed "was devoid of any legal analysis" and stated, "On the factum alone, leave should not be granted but there is an arguable case here and on that basis leave should be granted." In another, the researcher commented that the factum contained "long quotes of country evidence, claim is simply re-argued, doesn't address the errors which are very clear from the reasons," and, as to whether leave should have been granted, stated, "Yes based on reasons, but no based on record." In yet another, the researcher said of the memorandum, "Arguments not supported by legal authority; appearance of arguing with weight given to evidence," and as to the denial of leave stated, "The claim had its strengths-there was evidence to support key elements of the claim and the father was accepted in Canada two years earlier-leave could have been granted if a better record had been prepared."

In this category of cases, the conclusions of the researchers who examined the files were not that the judge had necessarily made a wrong determination. The burden of proof in any leave application is on the applicant. If the applicant (through counsel) fails to meet that burden, it would be acceptable judicial conduct to deny leave. On the other hand, it could also be acceptable judicial conduct (particularly in the life-and-death context of refugee determination) to go the extra mile, look beyond counsel's failings, and make an independent assessment of the application's overall merits. Thus, the third category of files is in a sort of grey zone in terms of assessing soundness; in some sense the leave determinations were justified, but in another sense, they were not.

\section{Findings on the Variable of the Quality of Legal Representation}

Globally, we found that 26 of 50 leave applications we studied suffered from poor legal representation (52\%). These included 22 of the 50 files (44\%) where poor legal representation was found by the researchers to have been a potential factor in the denial of leave, and 4 files where there had also been poor legal representation, but where the researchers felt that this had not been a factor in the leave determination. For instance, in one of the latter files the researcher gave

16. Leave was granted to two of the single females, three of the single males, and three of the families. 
Table 1. Substantive Shortcomings of Affidavits and Memoranda

\begin{tabular}{lcc}
\hline Type of substantive shortcoming & $\begin{array}{c}\text { Number of files } \\
\text { (out of 50) }\end{array}$ & 21 \\
\hline Failed to adequately recreate record & 18 & 42 \\
Failed to provide sufficient summary of facts & 17 & 36 \\
Memoranda failed to correctly or completely identify legal issues & 20 & 34 \\
Failed to link the facts and evidence to legal issues & 26 & 50 \\
Failed to provide sufficient legal research and analysis & 33 & 66 \\
Little or no discussion of leave test & 39 & 78 \\
Provided no reply memorandum & & 40 \\
\hline
\end{tabular}

the memorandum a failing grade but stated, "The claim was weak-it's a better H\&C [Humanitatian and Compasionate] case. It was family problems, family violence, but there was no nexus.... The denial of leave was justifiable." In another file, the researcher found the factum poorly done but noted that denial of leave was justified because key documents had been sent for verification by the tribunal and had come back fraudulent.

In the 22 files where poor representation was considered a possible explanation for the denial of leave, it is interesting to speculate how things might have been different had representation been adequate. At best, all 22 might have been granted, since the researchers felt they were otherwise viable. If so, the number of leave grants over the 50 files could have risen from 8 to 30 , raising the overall grant rate to $60 \%$. At worst, the 22 cases would have simply been subject to the vagaries of judge assignment alone (like the other 28 files where representation had not been a factor). In other words, since the researchers found leave was "unjustifiably denied" $46 \%$ of the time where representation had not been a factor (i.e., in 13 of 28 cases), 10 of the 22 might have been denied anyway. This, however, implies a potential rise in the grant rate from 8 out of 50 to 20 out of $50-40 \%$ overall, which coincides with the $39.54 \%$ rate at which judges grant judicial review in refugee cases after a full hearing (Rehaag, 2012, p. 51). Accordingly, ineffective legal representation could potentially have been a variable "skewing" the results obtained in previous quantitative studies in that it might have artificially depressed grant rates-although extreme caution must be exercised in drawing generalized conclusions on account of the small size and non-random selection method of our set of case files.

Apart from the question of the effect on outcomes, the scope of the problem of inadequate legal representation $(52 \%)$ was surprising to the researchers and gives the present study an unexpected dimension. Regardless of any issues in the statistical reliability of our data across the entire corpus of leave decisions, poor representation was potentially catastrophic for the individual claimants represented in our case files and therefore deserves further exploration.

Table 1 reveals the precise nature of counsel's shortcomings. For instance, 26 memoranda received a failing grade on substance and 11 on form. Fourteen affidavits (the vehicle through which the tribunal's record is recreated for the court) received a failing grade on substance and seven on form. The types of errors of form found by the researchers related to things such as failing to number paragraphs or employ headings in a memorandum and failing to attach exhibits in an affidavit. On substance, several affidavits were found to include large swaths of argument. More seriously, 21 affidavits failed to adequately recreate the entire record, in some cases leaving the judge with, quite literally, nothing to work with. Most of the problems, however, were with the memorandum. Seventeen memoranda failed to adequately or completely identify the legal issues, 18 failed to provide a sufficient summary of the facts, and 20 failed to link the facts and evidence to the legal issues. As for the legal research and analysis provided in the memoranda, all 26 files received a failing grade from the researchers. Some comments were: "Very little if any relevant case law was presented and there was probably quite a bit of relevant case law on delay"; "No research, sparse arguments.... Very poor. Arguments not supported by reference to the evidence in the record. Counsel argues bias without any evidentiary foundation"; "Little [research and analysis]. The factum felt like a re-arguing of a refugee claim"; "No legal analysis virtually"; and "Some legal research but the legal analysis was not focused, and it was hard to discern what argument the lawyer was making."

The use of boilerplate was identified in four cases. Disturbingly, six memoranda were of such a poor quality that 
the researchers suspected them to have been "ghostwritten"-i.e., a person not qualified to practise law prepared the application in the claimant's name, as if the claimant were unrepresented. In one such file, the researcher wrote,

The style of the factum was unorthodox and amateurish, and there was some boilerplate (for instance text from a stay factum was included). Serious issues were presented but with minimal supporting material. Some of the language was inflammatory. [For example:] "The Petitioner did not convince the panel ... that her spouse would still be interested in her. Let us send her back and we will see. 14000 women in Russia were killed in 2004 in domestic violence."17

In addition, in 39 files ( $78 \%)$, no reply memorandum was filed. This is potentially problematic in that, if no reply is filed, it is theoretically open to the judge to conclude that the claimant is not disputing the government's arguments or has no counter-arguments. Likewise, in 33 files (66\%), there was little, if any, time spent on discussion of the test for leave. The test to be applied by the judge would seem to be a crucial threshold issue in any leave application.

What was most striking about the files that suffered from ineffective legal representation was that counsel did not seem to have a solid grasp of administrative law principles or the scope and nature of judicial review. In other words, their focus tended to be on why their client deserved refugee status rather than why the RPD decision should be quashed on judicial review principles. For Federal Court judges, however, the reverse is true; they need to be pointed to reviewable errors in the underlying decision, and they need to have the record recreated for them. In the files we examined, far too many counsel neglected to do this. Examples of some claimants who appeared to be ill-served by their lawyers at the Federal Court included: a Chechen victim of domestic violence and rape in police custody who was refused solely on the basis of a lack of identity documents; a Chinese Christian who was held to an unreasonably high standard of religious knowledge at his refugee hearing; and a couple who feared the FARC guerrilla group in Colombia but were refused in a laconic and incoherent decision based on failure to claim in the United States.

Our findings on quality of legal representation were surprising, given what is at stake in refugee cases. We were cognizant that our study was based essentially on 8- to 13-year-old case files and that there had been several initiatives in the intervening years to improve training and supervision of refugee lawyers. ${ }^{18}$ Thus, we did some limited supplemental research into more recent case files. Using the same method and most of the same criteria as outlined above, one researcher selected and reviewed 10 negative refugee leave applications from $2016 .{ }^{19}$ In this substantially smaller group of files, we found that 5 out of the 10 files (50\%) displayed inadequate legal representation. Given that the incidence of inadequate representation essentially matched that in our original set of files $(52 \%)$, we felt fairly confident in concluding, even on the basis of this very small sample, that poorly prepared leave applications are possibly still a problem, and that it was still worth presenting our findings on the 50 original case files.

\section{Findings on the Variable of the Strength or Weakness of the Underlying Refugee Claim}

As noted above, the present research also explored whether Federal Court judges might be refusing leave at greater rates than the leave test would normally allow because a significant number of the underlying refugee claims were being perceived as "weak" in some way-i.e., the facts manifestly did not meet the refugee definition, the claims were proven fraudulent, or the claimant did not present as a credible witness. In the final analysis, five leave applications were identified as being "weak," based on the facts of the underlying refugee claim or because of fraud. All were found by the researchers to have been justifiably denied leave. In addition, twenty-nine leave applications involved cases where the claimant was found non-credible to some degree. Of these, two were granted.

It is very difficult to draw any reliable inferences from these observations, particularly within the confines of our qualitative approach. Nonetheless, only five cases qualified as "weak" based on the facts of the underlying claim, and one would likely need a larger number in order to support a postulate that this variable has the potential to explain low grant rates. Furthermore, the seeming correlation between negative leave outcomes and claimants with personal credibility problems is deceptive: practical experience suggests that a significant percentage of refugee claim refusals are based in some measure on adverse credibility findings to

17. The researcher also noted that the consultant who had very likely ghostwritten the application had been jailed for immigration fraud. 18. See, for example, Legal Aid Ontario, "Refugee Law Panel Standards."

19. Cases were generated by file number via a random integer generator, and only perfected leave applications involving leave applications filed by refused refugee claimants were included (but this time from either the initial hearing or the RAD). The group of files was not adjusted to reflect the geographical distribution found by Rehaag (2012); however, it just so happened that five were filed in Montreal and five in Toronto. 
begin with. ${ }^{20}$ Accordingly, our particular research does not readily support a conclusion that "weak" underlying refugee claims are skewing the leave grant rate to artificially low levels-although the door certainly remains open to further examination.

\section{Implications}

This exploratory study recognizes that refugee determinations are complex, difficult, and fraught with pitfalls. Our qualitative analysis of 50 leave files suggests that the refugee claimants who come before the Federal Court requesting leave for judicial review do not necessarily have weak underlying refugee claims. It also reinforces anecdotal discussion amongst refugee lawyers that the leave rate does not seem to coincide with the number of cases that could be heard at the Federal Court. Previous studies have focused on the presiding judge and the leave grant rates of the judges. Our manual review noted that many applications that deserved leave were inexplicably denied. ${ }^{21}$ This raises a question of whether the Court is actually applying the test for leave set out in the established case law, or whether the Court utilizes a different test.

Nonetheless, our analysis suggests that there is more at play here. Our findings imply that one of the most significant factors in obtaining leave at the Federal Court is not just that one has counsel, but that one's counsel is of high quality and puts forward a proper, professional, and sound application record. Our findings reinforce other research in the refugee law field indicating that legal representation matters (Rehaag, 2011; Schoeholtz and Jacobs, 2002; Kagan, 2006; Barutciski, 2012; Tomkinson, 2014, 2018, 2019). The study also supports research outside of refugee law that finds that the competency of one's legal representation can drive the outcome (Anderson \& Heaton, 2012; Thornton \& Gwin, 2012; Shanahan, Carpenter, \& Mark, 2016; Poppe \& Rachlinski, 2016; Miller, Keith, \& Holmes, 2015). While the methodology of our study had some limitations, being "in the trenches" allowed us to partially lift the veil on judicial decision making to reveal different findings from a purely quantitative study.

Indeed, this research exposes the limitations and potential distortions associated with purely statistical analysis. For instance, Gould et al. did attempt to measure the effect of legal representation on leave grant rates, but came to the conclusion that judge assignment was likely still the determinative factor notwithstanding (Gould et al., 2010, p. 475). This conclusion is not supported by our qualitative study. Likewise, Rehaag's 2012 study discussed the possibility that variations in quality of counsel could account for low and inconsistent grant rates, but ultimately concluded that it was "unlikely" that poor counsel could account for these phenomena (Rehaag, 2012, p. 28). ${ }^{22}$ Again, our study does not support this conclusion. Further, our findings support Rehaag's earlier work on the impact of legal representation in refugee cases in his 2011 study on the role of counsel in IRB decisions (Rehaag, 2011). Our findings (and indeed together with Rehaag's 2011 study) posit that we should not be so quick to dismiss the quality of legal representation as a major factor in the context of leave applications. It also worth noting that the statistical studies paint a somewhat dystopian picture at the Federal Court because of their persistent focus on the massive grant-rate variations across judges. Our qualitative study arguably presents a more nuanced picture. ${ }^{23}$

Overall, we found that $52 \%$ of the leave applications we examined suffered from ineffective legal representation. These preliminary findings not only have policy implications but also raise questions. Are refugee lawyers sufficiently educated or trained in submitting leave applications or in administrative law? Do they have adequate resources to devote to improving the quality of their submissions to the Federal Court, or are there constraints, such as limited legal aid funding (Mojtehedzadeh, 2019; Keung, 2017; СвС News, 2017)? Indeed, this question is of more relevance today, given

20. An informal survey of judicial review judgments in immigration cases for June 2005 and June 2010 was conducted by the researchers. In June 2005, 39\% of immigration judgments involved judicial review of a negative RPD decision. In $59 \%$ of these cases, the underlying RPD decision had been based at least partly on an adverse finding of credibility. For June 2010, $16 \%$ of immigration judgments involved judicial review of a negative RPD decision, and $52 \%$ of these decisions had been based at least partly on adverse findings of credibility.

21. As noted earlier, we found 13 applications that were unjustifiably denied leave, despite adequate legal representation.

22. Rehaag (2012) did not code for quality of counsel, but seemed to have used city of filing as a proxy on the grounds that legal aid might be more accessible in some cities than others. He found that leave applications filed in Toronto were $1.42 \%$ more likely to be granted than those filed in Montreal; however, this was not a big enough difference statistically to account for the massive variations in grant rates across judges (pp. 28-29). In our data, in 8 of the 18 Montreal files (44\%) and 18 of the 28 Toronto files (64\%) there was poor legal representation. Two of the 18 Montreal files were granted, and 2 of the 28 Toronto files were granted.

23. As noted above, the researchers agreed with the judges' decisions in 15 of the 28 files where quality of counsel was not a factor. Of these 15 , the researchers agreed with seven negative decisions and eight positive ones. 
recent cuts to Legal Aid Ontario eliminating provincial legal aid funding for refuge cases (Canadian Press, 2019). Is the situation serious enough to warrant the involvement of provincial law societies, particularly given the vulnerability of the clientele? Does the Federal Court itself need to develop a policy for dealing with substandard counsel on leave applications or review how they are assessing leave applications? Follow-up research and policy attention is urgently required on these points.

As it stands, this exploratory study is a good and bad news story. The bad news is that some lawyers may not be doing all they can and should be doing. The result is dire, as such claimants lose access to a review process that is otherwise guaranteed by law. The good news is that we as lawyers can do something about this; we are more in control of leave outcomes than previously thought and therefore less subjugated to the judicial "luck of the draw."

\section{Conclusion}

This research is a gateway to further, in-depth qualitative research on the leave process in Federal Court refugee proceedings. While in the context of this study we cannot definitively assess the extent and relative importance of poor-quality legal representation as a factor influencing leave rates, our research does indicate that it is an important issue in the lives behind the cases. To this extent, we hope that our research provokes a moment of self-reflection among all refugee lawyers, one in which we ask ourselves whether and how we can better advocate for a population that requires the very best in legal representation.

\section{References}

Anderson, J. M., \& Heaton, P. (2012). How much difference does the lawyer make? The effect of defense counsel on murder case outcomes. Yale Law Journal, 122(1), 154-217. Arulampalan v Canada (1989), 8 Imm LR (2d) 172.

Bains v Canada (1990), 47 Admin LR 317.

Barutciski, M. (2012). The impact of the lack of legal representation in the Canadian asylum process. UNHCR. https://www.refworld.org/docid/510ofbeo2.html

Butler, D. (2011, November 27). Federal court judges independent and free of ideology, retired chief justice says. Ottawa Citizen.

Canadian Council for Refugees. (2012). The experience of refugee claimants at refugee hearings at the immigration and refugee board.

Canadian Council for Refugees. (2014). The experience of refugee claimants at refugee hearings at the immigration and refugee board.

Canadian Press. (2019, April 15). Legal Aid Ontario will stop accepting new immigration, refugee cases follow- ing cuts. https://www.cbc.ca/news/canada/toronto/ legal-aid-ontario-cuts-1.5099348

СBC News. (2017, June 28). BC legal aid suspends immigration and refugee services due to lack of funding. https:// www.cbc.ca/news/canada/british-columbia/b-c-legalaid-suspends-immigration-and-refugee-services-dueto-lack-of-funding-1.4181352

Federal Courts Citizenship. Immigration and Refugee Protection Rules, soR/93-22, s 5.

Gould, J. B., Sheppard, C., \& Wheeldon, J. (2010). A refugee from justice? Disparate treatment in the federal court of Canada. Law \& Policy, 34(4), 454-486. https://doi. org/10.1111/j.1467-9930.2010.00325.x

Greene, I., Baar, C., McCormick, P., Szablowski, G. \& Thomas, M. (1998). Final appeal: Decision-making in Canadian courts of appeal. James Lorimer \& Company.

Greene, I., \& Shaffer, P. (1992). Leave to appeal and leave to commence judicial review in Canada's refugee-determination system: Is the process fair? International Journal of Refugee Law, 4(2), 71-83. https://doi.org/10.1093/ $\mathrm{ijrl} / 4 \cdot 1.71$

Immigration and Refugee Protection Act, SC 2001, c 27.

Kagan, M. (2006). Frontier justice: Legal aid and UNHCR refugee status determination in Egypt. Journal of Refugee Studies, 19(1), 45-68. https://doi.org/10.1093/jrs/fejoo2

Keung, N. (2017, March 31). As refugee numbers surge, federal legal aid funding shrinks. Toronto Star.

Krishnapillai v Canada (2001) 378 FCA, [2002] 3 FC 4.

Legal Aid Ontario. Refugee law panel standards. http://www. legalaid.on.ca/en/info/panel_standards_refugee.asp

Macklin, A. (2009). Asylum and the rule of law in Canada: Hearing the other (side). In S. Kneebone (Ed.), Refugees, asylum seekers and the rule of law: Comparative perspectives (pp. 78-121). Cambridge University Press.

Miller, B., Keith L. C., \& Holmes, J. S. (2015). Leveling the odds: The effect of quality legal representation in cases of asymmetrical capability. Law \& Society Review 49(1), 209-239. https://doi.org/10.1111/lasr.12123

Mojtehedzadeh, S. (2019, April 11). Cuts to legal aid leave refugees, immigrants in the lurch. Toronto Star.

Poppe, E. S. T., \& Rachlinski, J. J. (2016). Do lawyers matter? The effect of legal representation in civil disputes. Pepperdine Law Review 43(4), 881-942.

Rehaag, S. (2011). The role of counsel in Canada's refugee determination system: An empirical assessment. Osgoode Hall Law Journal, 49(1), 71-116. https://digitalcommons. osgoode.yorku.ca/ohlj/vol49/iss1/3/

Rehaag, S. (2012). Judicial review of refugee determinations: The luck of the draw? Queens Law Journal, 38(1), 1-58. https://journal.queenslaw.ca/sites/journal/files/Issues/ Vol\%2O38\%20i1/1.\%2oRehaag.pdf 
Rehaag, S. (2019). Judicial review of refugee determinations (II): Revisiting the luck of the draw. Queen's Law Journal 45(1) $1-36$.

Rehaag, S., \& Grant, A. (2016). Unappealing: An assessment of the limits on appeal rights in Canada's new refugee determination system. UBC Law Review, 49(1), 203-274.

Rousseau, C., Crépeau, F., Foxen, P., \& Houle, P. (2002). The complexity of determining refugeehood: A multidisciplinary analysis of the Canadian immigration and refugee board. Journal of Refugee Studies, 15(1), 43-70. https://doi.org/10.1093/jrs/15.1.43

Schoenholtz, A. I., \& Jacobs, J. (2002). The state of asylum representation: Ideas for change. Georgetown Immigration Law Journal, 16(4), 739-772.

Shakespeare, W. (1984). The Oxford Shakespeare: Julius Caesar (A. Humphreys, Ed.). Oxford University Press.

Shanahan, C. F., Carpenter A. E., \& Mark, A. (2016). Lawyers, power, and strategic expertise. Denver Law Review, 93(2), 469-522.

Singh $v$ Canada (Minister of Employment and Immigration), [1985] 1 SCR 177.

Thornton, E., \& Gwin, B. (2012). High-quality legal representation for parents in child welfare cases results in improved outcomes for families and potential cost savings. Family Law Quarterly, 46(1), 139-154.

Tomkinson. S. (2014). The impact of procedural capital and quality counsel in the Canadian refugee determi- nation process. International Journal of Migration and Border Studies, 1(3), 276-29o. https://doi.org/10.1504/ IJMBS.2014.068969

Tomkinson, S. (2018). Who are you afraid of and why? Inside the black box of refugee tribunals. Canadian Public Administration, 61(2), 184-204. https://doi.org/10.1111/ capa.12275

Tomkinson, S. (2019). Trois nuances de lexpertise stratégiquez: le rôle des avocats dans la procédure d'asile. Politique et Sociétés, 38(1), 99-128. https://doi. org/10.7202/1058292ar

Virk v Canada (1991), 13 Imm LR (2d) 119.

Jamie Liew is an immigration lawyer and an associate professor at the University of Ottawa, Faculty of Law. She can be reached at jamie.liew@uottawa.ca.

Pia Zambelli is a refugee lawyer practising in Montreal and a former member of the Immigration and Refugee Board of Canada. She can be reached at zambelli@videotron.ca.

Pierre-André Thériault is a doctoral candidate at Osgoode Hall Law School. He can be reached at theriaultpa@gmail.com.

Maureen Silcoff is a partner at Silcoff Shacter. She can be reached at msilcoff@silcoffshacter.com. 